\title{
Hydration and dehydration at the tropical tropopause
}

\author{
C. Schiller, J.-U. Grooß, P. Konopka, F. Plöger, F. H. Silva dos Santos, and N. Spelten \\ Forschungzentrum Jülich GmbH, ICG-1, 52425 Jülich, Germany \\ Received: 22 July 2009 - Published in Atmos. Chem. Phys. Discuss.: 24 August 2009 \\ Revised: 8 December 2009 - Accepted: 9 December 2009 - Published: 23 December 2009
}

\begin{abstract}
High-resolution water measurements from three tropical airborne missions in Northern Australia, Southern Brazil and West Africa in different seasons are analysed to study the transport and transformation of water in the tropical tropopause layer (TTL) and its impact on the stratosphere. The mean profiles are quite different according to the season and location of the campaigns, with lowest mixing ratios below 2 ppmv at the cold point tropopause during the Australian mission in November/December and high TTL mixing ratios during the African measurements in August. We present backward trajectory calculations considering freezedrying of the air to the minimum saturation mixing ratio and initialised with climatological satellite data. This trajectorybased reconstruction of water agrees well with the observed $\mathrm{H}_{2} \mathrm{O}$ average profiles and therefore demonstrates that the water vapour set point in the TTL is primarily determined by the Lagrangian saturation history. Deep convection was found to moisten the TTL, in several events even above the cold point up to $420 \mathrm{~K}$ potential temperatures. However, our study does not provide evidence for a larger impact of these highlylocalised events on global scales.
\end{abstract}

\section{Introduction}

The entry of water vapour into the stratosphere is controlled by the interplay of transport and freeze-drying primarily in the tropics (e.g. Fueglistaler et al., 2009, and references therein). Several hypotheses have been proposed to explain the dryness of the stratosphere and the variability of the water entry. The average temperature and corresponding saturation ice mixing ratio at the tropical tropopause are higher than the observed average water entry. Therefore, Newell

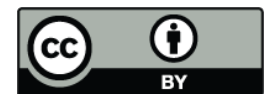

Correspondence to: C. Schiller (c.schiller@fz-juelich.de) and Gould-Stewart (1981) proposed fountain regions for the entry into the stratosphere, where tropopause temperatures are coldest, as the region of the Western Pacific during the northern hemispheric winter and the Bay of Bengal during northern hemispheric summer. Taking up the idea of dedicated regions of effective freeze-drying, Holton and Gettelman (2001) proposed that horizontal advection through these cold tropopause regions is causing the dryness of air before entering the stratosphere, rather than enhanced upwelling in these particular regions. Several climatological studies based on a Lagrangian approach (e.g. Jensen and Pfister, 2004; Fueglistaler et al., 2005; Fueglistaler and Haynes, 2005) demonstrated that saturation mixing ratios along trajectories provide a good first-order estimate for stratospheric water vapour mixing ratios and their variability on seasonal and interannual scales. Such studies confirm the important role of the Western Pacific and the Asian monsoon regions to control the moisture flux into the stratosphere.

As an alternative hypothesis to large-scale dehydration, Danielsen (1993) and Sherwood and Dessler (2000) postulated that dehydration occurs primarily in deep overshooting convection. Extremely low temperatures in cumulonimbus turrets may lead to extremely dry air, providing that the air is exposed to lowest temperatures for a sufficiently long time to allow for the ice particles to sediment out. However, based in part on the data of our study, Corti et al. (2008) presented experimental evidence that overshooting convection has a hydrating rather than a dehydrating effect close to the tropical tropopause. Similar conclusions have been drawn from model simulations recently (Chaboureau et al., 2007; Grosvenor et al., 2007; Jensen et al., 2007). Upscaling of overshoot events still reveals a large uncertainty for the estimation of their global impact on the stratospheric water budget.

In this paper, we present airborne high-resolution water measurements from three tropical sites at different seasons, i.e. from Northern Australia and from Southern Brazil during

Published by Copernicus Publications on behalf of the European Geosciences Union. 
Table 1. Overview of tropical aircraft experiments for this study.

\begin{tabular}{|c|c|c|c|c|}
\hline Experiment & Base & Time & $\begin{array}{l}\text { No. of } \\
\text { local }+ \\
\text { transfer } \\
\text { flights }\end{array}$ & reference \\
\hline SCOUT-O3 & $\begin{array}{l}\text { Darwin, } \\
\text { Australia } \\
\left(12^{\circ} \mathrm{S}, 139^{\circ} \mathrm{W}\right)\end{array}$ & $\begin{array}{l}31 \text { October- } \\
17 \text { December } 2005\end{array}$ & $8+12$ & $\begin{array}{l}\text { Vaughan et al. (2008) } \\
\text { Brunner et al. (2009) } \\
\text { http://www.ozone-sec.ch.cam.ac.uk/scout_o3/ }\end{array}$ \\
\hline TroCCiNOx & $\begin{array}{l}\text { Aracatuba, } \\
\text { Brazil } \\
\left(21^{\circ} \mathrm{S}, 58^{\circ} \mathrm{E}\right)\end{array}$ & $\begin{array}{l}18 \text { January- } \\
18 \text { February } 2005\end{array}$ & $8+6$ & http://www.pa.op.dlr.de/troccinox \\
\hline AMMA-SCOUT-O3 & $\begin{array}{l}\text { Ouagadougou, } \\
\text { Burkina Faso } \\
\left(12^{\circ} \mathrm{N}, 1^{\circ} \mathrm{W}\right)\end{array}$ & $\begin{array}{l}29 \text { July- } \\
17 \text { August } 2006\end{array}$ & $5+4$ & $\begin{array}{l}\text { Cairo et al. (2009) } \\
\text { http://www.isac.cnr.it/ utls/m55amma/ }\end{array}$ \\
\hline
\end{tabular}

boreal winter and from West Africa during boreal summer. The profiles from the different campaigns are compared in order to determine the characteristic water distribution for each region and season studied. Trajectory studies are used to compare the recent saturation history of the probed air masses with the observed water vapour mixing ratios. We investigate to what extent water vapour can be reconstructed based on trajectories which consider convection only in large scale mean vertical transport rates. The impact of deep convection is studied for individual cases providing independent evidence for persistent moistening of the tropopause region.

\section{Experiments}

The water measurements presented here were obtained by the Fast In-situ Stratospheric Hygrometer (FISH) which is based on the Lyman- $\alpha$ photofragment fluorescence technique. Instrument and calibration procedure are described in Zöger et al. (1999). The FISH inlet is mounted forward-facing thus measuring total water, i.e. the sum of gas-phase water and ice particles. The procedure to correct the data for oversampling of ice particles is discussed in Schiller et al. (2008). FISH was mounted on the Russian M55 Geophysica high-altitude aircraft with a maximum ceiling of $20 \mathrm{~km}$. Thus measurements in the TTL and lower stratosphere were possible.

We present data from three tropical experiments (Table 1): The Tropical Convection, Cirrus and Nitrogen Oxide experiment (TroCCiNOx) in January and February 2005 from Araçatuba, Brazil, the Stratospheric-Climate Links with Emphasis on the Upper Troposphere and Lower Stratosphere (SCOUT-O3) tropical mission in November and December 2005 from Darwin, Australia, and the African Monsoon Multidisciplinary Analysis (AMMA/SCOUT-O3) experiment in August 2006 from Ouagadougou, Burkina Faso. All three campaigns covered the convective season at the locations in Southern America, West Africa and Northern Australia, with the two Southern Hemisphere missions taking place during boreal winter and the Northern Hemisphere mission in Africa during boreal summer.

The SCOUT-O3 flight routes from Darwin are displayed in Fig. 1a. They include local flights in the vicinity of convection as well as long-range flights to probe the inflow and outflow region of convection and the large scale background TTL. Also the measurements during the transfer flights from and to Europe via Cyprus, Arabian Emirates, India, Thailand, and Borneo covered a wide area in the tropics. An overview on the flight patterns, objectives and meteorology of the campaign is given in Vaughan et al. (2008) and Brunner et al. (2009), respectively. Compared to the mesoscale convective system observed over Brazil and West Africa, regularly occurring isolated storms localised over the Tiwi Islands north of Darwin, so-called "Hector" storms (May et al., 2009, and references therein), were investigated during several flights.

Similarly, the TroCCiNOx flights include local flights to investigate convective systems (4, 5 and 18 February 2005) and long-range flights to investigate the background TTL and stratosphere (Fig. 1b). Measurements were also made during the transfer route from and to Europe via Spain, Cape Verde Islands, and Recife (Brazil). The operational region in Brazil was located at the edge of the tropics, so also the mixing of tropical with extratropical air was detected during some flights (Konopka et al., 2007). Continental convective systems penetrating the tropopause have been probed by the aircraft on 4 February 2005 (see also Chaboureau et al., 2007) and 5 February 2005.

During the flights over Africa in the frame of AMMA/SCOUT-O3 (overview of flight patterns and meteorology by Cairo et al., 2009), no direct observations of deep convective systems could be made within the range of the 

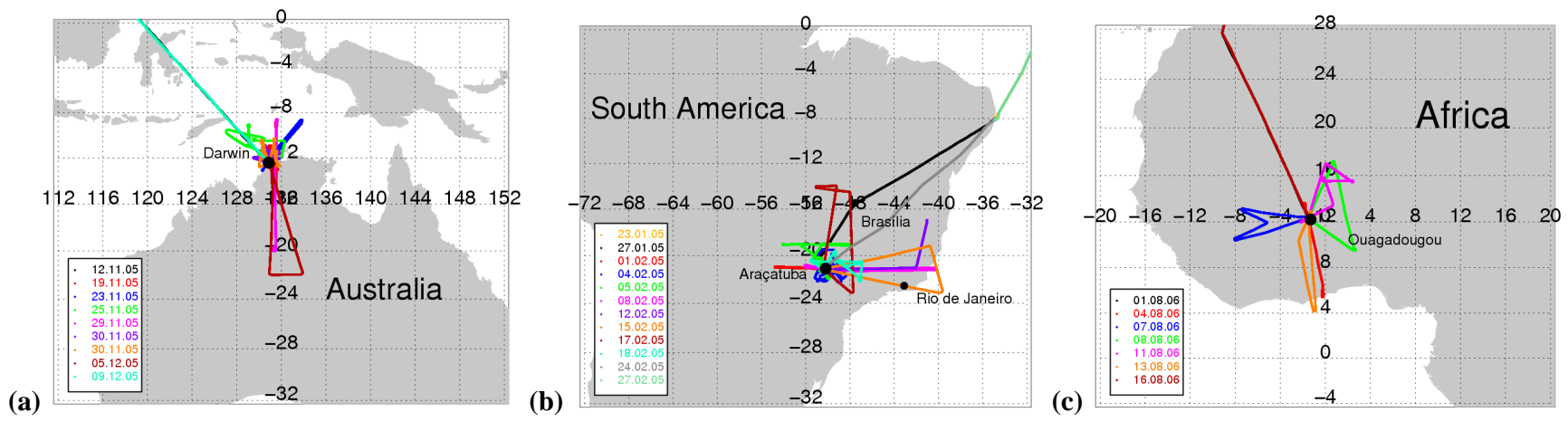

Fig. 1. Routes of local flights during (a) SCOUT-O3 with operation base in Darwin, Australia (b) TroCCiNOx with operation base in Araçatuba, Brazil and (c) AMMA/SCOUT-O3 with operation base in Ouagadougou, Burkina Faso. Parts of the transfer flights to and from Europe are included.

aircraft; flight routes are given in Fig. 1c. The multi-cell convective systems of the African monsoon occurred typically upwind, i.e. east of the flight routes as could be identified from satellite IR images. The instrumented transfers from and to Europe covered mainly the transition to extratropical regions.

\section{Data/Results}

In this paper, the vertical distribution of water vapour in the TTL and lower stratosphere is discussed and compared for the different campaign locations and seasons. The flights listed in Table 1 include measurements of at least two profiles during ascent and descent, most of the local flights include additional profiling information from dives. The vertical information may, according to the flight pattern, be gathered over horizontal distances of several hundred kilometres.

In Fig. 2, the measured water profiles are displayed for the three campaigns, colour-coded with respect to the relative humidity with respect to ice $\left(\mathrm{RH}_{\text {ice }}\right)$. As FISH measures total water, measurements above $100 \% \mathrm{RH}_{\text {ice }}$ in Fig. 2 may include observations in clouds, in particular for $\mathrm{RH}_{\text {ice }}$ exceeding the threshold of homogeneous ice formation (Koop et al., 2000). We therefore denote the relative humidity measurements in following by $\mathrm{RH}_{\text {total }}$. The profiles are rather compact around a mean value - except data obtained in clouds and specific situations to be discussed in Sect. 4.2. They show specific characteristics for each campaign, reflecting the regional and seasonal conditions.

The lowest mixing ratios of less than 2 ppmv are observed during SCOUT-O3 at potential temperatures $\theta=370-380 \mathrm{~K}$, almost coinciding with the local cold point tropopause which was observed around $375 \mathrm{~K}$ on average for this period and location (Brunner et al., 2009). The corresponding temperatures were low at these altitudes, i.e. on average $-85^{\circ} \mathrm{C}$, therefore frequently $\mathrm{RH}_{\text {total }}$ close to saturation or clouds were observed in the vicinity of the tropopause. Striking features are layers of high $\mathrm{H}_{2} \mathrm{O}$ and cloud occurrence above the tropopause from observation of deep convection above Tiwi Island, the Hector storms (see Sect. 4.2). High $\mathrm{RH}_{\text {total }}$ at the cold point tropopause is indicative for effective freezedrying down to very low mixing ratios in this region and season.

Also during TroCCiNOx, very low mixing ratios were observed, in few cases also close to 2 ppmv. The average minimum is found at slightly higher altitudes, but still close to the average cold point tropopause, which was found between 370 and $380 \mathrm{~K}$, depending on the actual conditions. As the most obvious difference to the SCOUT-O3 observations, mean cold point temperatures were higher, i.e. $-79^{\circ} \mathrm{C}$; thus most of the measurements were made at subsaturated conditions outside clouds. Clouds and high $\mathrm{RH}_{\text {total }}$ were only observed during the flights on 4 and 5 February 2005 when convection reached the tropopause. Again, enhanced water vapour and ice particles were injected into the stratosphere up to about $415 \mathrm{~K}$ during these events.

The AMMA/SCOUT-O3 profiles look very different to those of the two other campaigns, both in absolute values and in the stratospheric gradient. At the cold-point tropopause with an average location at $370 \mathrm{~K}$ for this campaign, the water mixing ratio has a mean value of $5 \mathrm{ppmv}$ and shows a pronounced change of the slope, but decreases further in the stratosphere. Balloon measurements in the same region (Khaykin et al., 2009) show the $\mathrm{H}_{2} \mathrm{O}$ minimum at approximately $20 \mathrm{~km}$ altitude, corresponding to the maximum ceiling of the Geophysica aircraft from which our data are obtained. Here, the mean mixing ratio obtained from the FLASH-B instrument is $4.4 \mathrm{ppmv}$ and thus consistent with our measurements at these altitudes $(4.1 \mathrm{ppmv})$. Temperatures at the tropopause are significantly higher than during SCOUT-O3 but similar to those from TroCCiNOx. With the higher $\mathrm{H}_{2} \mathrm{O}$ values, $\mathrm{RH}_{\text {total }}$ frequently is close to $100 \%$ in a thin layer around the cold point, 

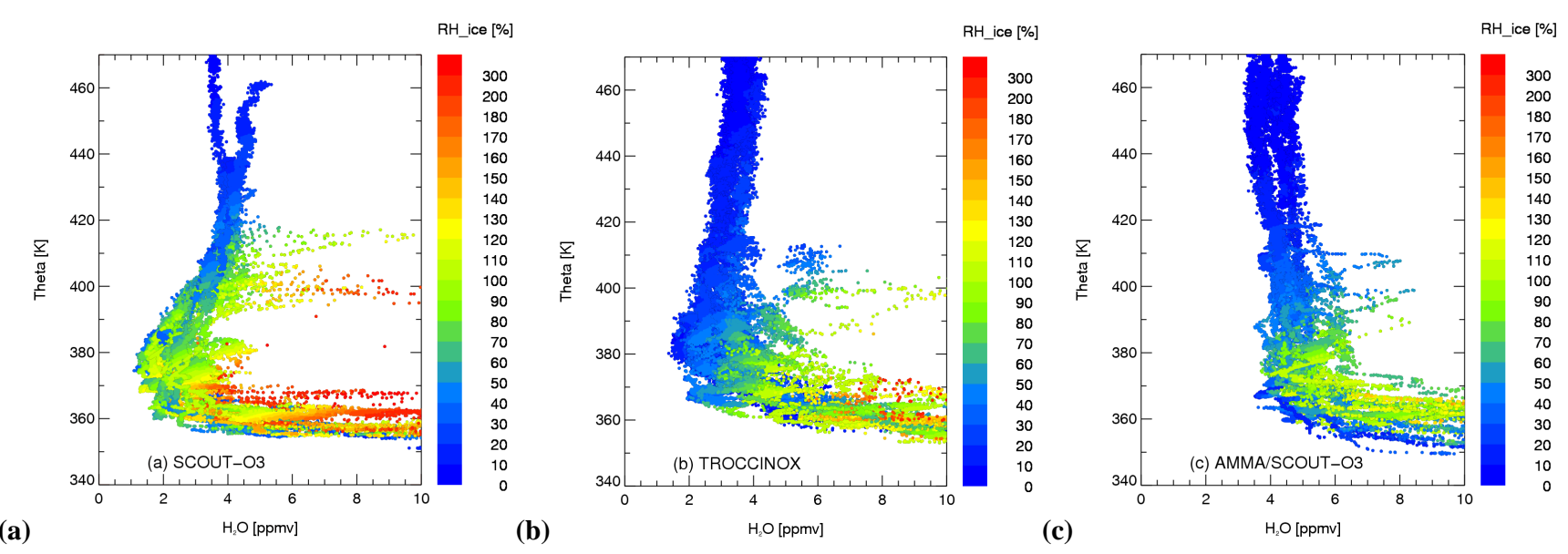

Fig. 2. Vertical profiles of total water during the tropical aircraft campaigns (a) SCOUT-O3 in Northern Australia (November 2005), (b) TroCCiNOx in Brazil (February 2005), and (c) AMMA/SCOUT-O3 in West Africa (August 2008). Colour code denotes the relative humidity with respect to ice.

sometimes accompanied by cirrus cloud occurrence. Though no Geophysica flights directly above deep convection were made during AMMA/SCOUT-O3, layers of enhanced $\mathrm{H}_{2} \mathrm{O}$ above the tropopause are detected in three profiles.

For comparison, our data from February-March 1999 over the Indian Ocean during the APE-THESEO campaign (MacKenzie et al., 2006) show similar to the SCOUT-O3 data extremely low $\mathrm{H}_{2} \mathrm{O}$ mixing ratios with saturation at the cold point tropopause. However, during that campaign no convection reaching the tropopause level was probed, but ultrathin cirrus at the tropopause occurred quite frequently (Peter et al., 2003). The water minimum was at slightly higher altitudes than during SCOUT-O3.

Figure 3 summarises the average water profiles obtained during the four tropical Geophysica missions. Here, data in convection-induced ice clouds have not been included as these phenomena lead to a local moistening which might not be representative for the global $\mathrm{H}_{2} \mathrm{O}$ distribution (see Sect. 4). Figure 3 also shows frostpoint hygrometer measurements over Indonesia during the SOWER campaign in early January 2006 (Vömel et al., 2007), which are obtained close to our SCOUT-O3 data in a nearby region. The averaged SCOUT-O3 and SOWER profiles agree well above $380 \mathrm{~K}$ in terms of absolute values and slope, at lower altitudes the local conditions are likely the reason for slightly higher mixing ratios over Darwin with a strong convective impact. Also the profiles of Kelly et al. (1993) obtained during the STEP campaign January 1987 from Darwin are very close to the SCOUT-O3 profiles in quantity and slope. The TroCCiNOx and APE-THESEO data show slightly lower values above $410 \mathrm{~K}$ compared to SCOUT-O3. As these campaigns were carried out three months later in season, the difference would be consistent with an upward propagation of the dehydration signal, the so-called tape recorder (Mote et al., 1996) in that time: using a clear-sky cooling rate of $0.6 \mathrm{~K} / \mathrm{d}$ for this region (e.g. Corti et al., 2005), air parcels are lifted from the cold point tropopause to the $410-430 \mathrm{~K}$ region in this time. We cannot exclude, however, that a year-to-year variability is overlaid to this phenomenon (Sect. 4.1.3), and the regional influence at these altitudes leads to zonal asymmetries, but to first order the data reflect the upward propagation of the tape recorder signal with season. Close to the tropopause, the $\mathrm{H}_{2} \mathrm{O}$ mixing ratios during TroCCiNOx are higher than the very low values during SOWER, SCOUT-O3 and APETHESEO and therefore account for moister and warmer conditions at the edge of the tropics over South America. The AMMA/SCOUT-O3 obtained in NH summer are higher by about $2-3$ ppmv at $380 \mathrm{~K}$ compared to the other campaigns, consistent with the higher water vapour entry in that season and similar to e.g. the historical Panama data in September 1980 by Kley et al. (1982) and sonde data from Costa Rica (Vömel et al., 2007). Above $410 \mathrm{~K}$, the absolute mixing ratios are very similar for all campaigns (including the SOWER, Panama and Cost Rica data), thus the tape recorder amplitude is already smeared-out or masked by regional or year-to-year variability. However, the different slopes between the NH summer and winter data are still indicative for the upwelling of the freeze-drying signal from the cold point region with season.

\section{Discussion}

The water vapour profiles obtained during the three missions TroCCiNOx, SCOUT-O3 and AMMA/SCOUT-O3 provide a sample of data representing different tropical sites and seasons, each with its specific characteristics. In this Section, we will examine the hydrating and dehydrating processes 


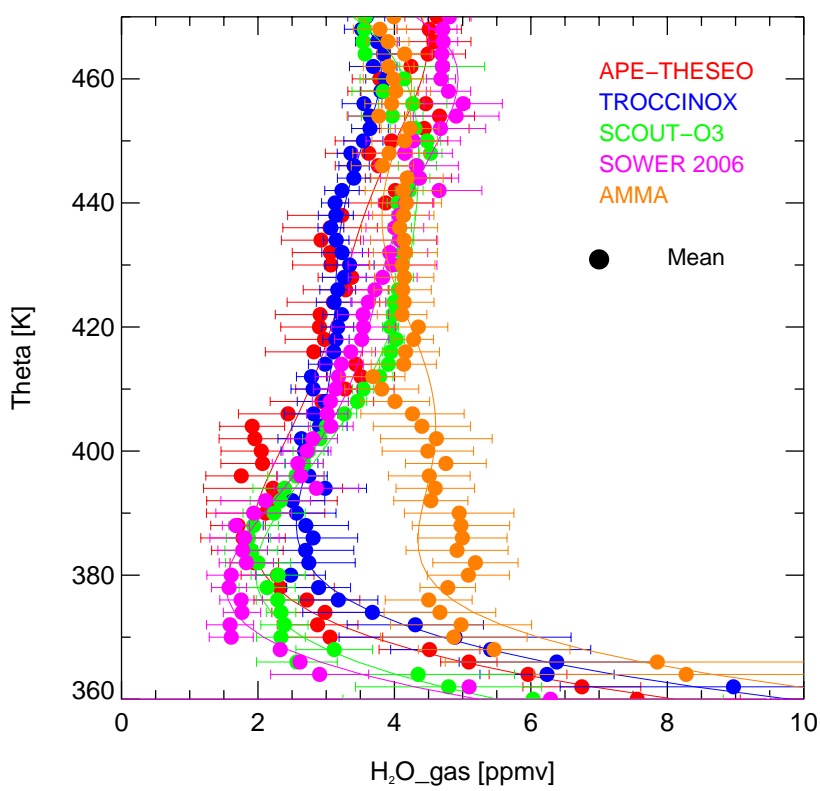

Fig. 3. Comparison of mean water vapour profiles of the TroCCiNOx, SCOUT-O3, AMMA/SCOUT-O3 campaigns with those obtained during the APE-THESEO, SOWER, Panama and Costa Rica missions (references see text). FISH data measured in clouds are not considered.

causing the specific $\mathrm{H}_{2} \mathrm{O}$ distributions in particular in the vicinity of the cold point tropopause of the individual missions. Though the coverage of these selected missions covers neither the complete tropical belt nor a full seasonal cycle, the analysis will provide a thorough insight in tropical hydration and dehydration mechanisms and the role of specific tropical regions. Emphasis will be laid on the role of deep convection and the large-scale advection during which the water vapour content of air parcels are changed.

\subsection{Dehydration at the cold point tropopause}

For the Darwin flights during SCOUT-O3, saturation conditions were observed frequently in a broad altitude band around the cold point, indicative of local dehydration down to the very low mixing ratios of 2 ppmv or less. For AMMA/SCOUT-O3, saturation is reached up to the cold point in part of the profiles, and for TroCCiNOx, $\mathrm{H}_{2} \mathrm{O}$ mixing ratios at the tropopause were usually lower than the local saturation. Therefore, in many cases the corresponding freeze drying events must have occurred earlier and at different locations.

We use backward trajectories ending at $1 \mathrm{~s}$ intervals along the flight paths of the three missions to determine the temperature history of the observed air parcels and to reconstruct its water content. The deterministic trajectories are calculated using the Chemical Lagrangian Model of the Stratosphere (CLaMS), which is driven by ECMWF meteorological fields.
For the vertical parameterisation of the tropopause region, a hybrid coordinate is chosen as described by Konopka (2007). Above a pressure of $100 \mathrm{hPa}$, approximately the tropical tropopause pressure, the hybrid vertical coordinate is equal to the potential temperature, with the cross-isentropic vertical velocity deduced from clear-sky radiation (Morcrette scheme). Below, coordinate surfaces smoothly transform into being parallel to pressure surfaces, with the vertical velocity smoothly transforming into the ECMWF vertical wind. Hence, our trajectory calculation is purely diabatic above the tropopause, gradually transforming into kinematic below.

Sensitivity studies with the cross-isentropic velocity deduced from the ERA-Interim reanalysis total diabatic heating rate, including clear-sky and cloud radiative effects and latent heat release (Plöger et al., 2009), show that the change in the resulting water profiles is less than $0.1 \mathrm{ppmv}$. Therefore, restricting to clear-sky radiative heating rates above $100 \mathrm{hPa}$ is not a shortcoming of our study.

ECMWF temperatures at the tropical tropopause are generally in good agreement with corresponding radiosonde measurements, with standard-level biases of the order of $0.5 \mathrm{~K}$ or less (Simmons et al., 1999; Randel et al., 2004b). However a slightly larger warm bias is apparent for the $\mathrm{NH}$ winter season for the lowest temperatures.

$\mathrm{RH}_{\mathrm{ice}}=100 \%$ is found to be the average and most frequent value in cirrus clouds down to the low temperature conditions in the tropics (Krämer et al., 2009). The nucleation of such clouds occurs however at higher $\mathrm{RH}_{\text {ice }}$ (Koop, 2000), i.e. at higher initial water concentrations which are then freeze-dried to a lower value. Jensen et al. (2001) pointed out, that in the tropics low ice crystal numbers and rapid sedimentation might not allow dehydration of air from the nucleation threshold down to saturation $\left(\mathrm{RH}_{\mathrm{ice}}=100 \%\right)$. Therefore, we tested the sensitivity of saturation mixing ratio along the trajectories considering a relative humidity over ice $\mathrm{RH}_{\mathrm{ice}}=100 \%$ and $130 \%$, respectively. Hereby, the mixing ratio at the end of the trajectory can be changed by up to 0.3 ppmv, providing that a major dehydration had occurred (see Sect. 4.1.3).

\subsubsection{Saturation history}

Figure $4 \mathrm{a}-\mathrm{c}$ shows averaged total water data profiles measured by FISH (black dots, including their standard deviation grey-shaded) together with the cold point history for the tropical flights of the three campaigns SCOUT-O3, TroCCiNOx and AMMA/SCOUT-O3, respectively; FISH data include the local flights plus transfers made between $0^{\circ}$ and $30^{\circ} \mathrm{S}$, between $30^{\circ} \mathrm{S}$ and $30^{\circ} \mathrm{N}$, and between $0^{\circ}$ and $30^{\circ} \mathrm{N}$, respectively. Figure $4 \mathrm{a}-\mathrm{c}$ shows profiles of the minimum saturation water vapour mixing ratio calculated along backward trajectories, for 10-day backward trajectories (green crosses) and for 30-day backward trajectories (red crosses). A longer trajectory history results in lower values of the minimum saturation mixing ratios primarily for two reasons: first, 

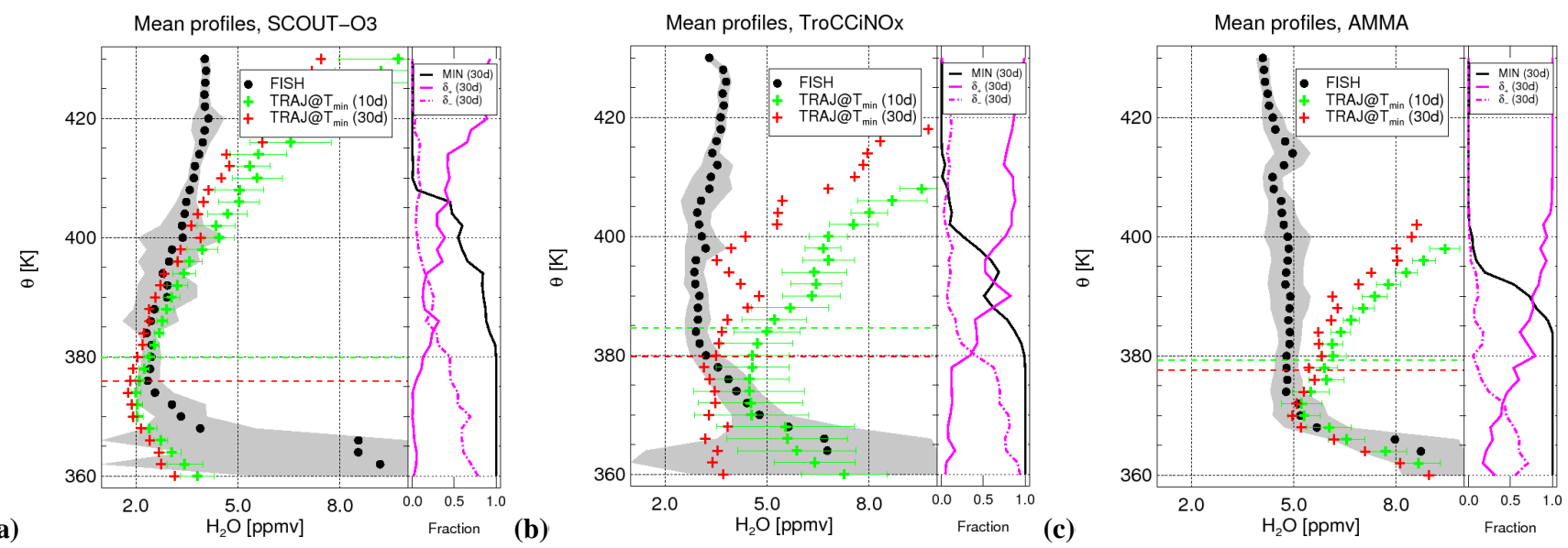

Fig. 4. Mean vertical profiles of $\mathrm{H}_{2} \mathrm{O}$ measured during (a) SCOUT-O3 (b) TroCCiNOx and (c) AMMA/SCOUT-O3, including tropical parts of transfer routes to and from Europe (black dots, binned for $\theta$ intervals of $2 \mathrm{~K}$; grey envelope denotes standard deviation). Minimum saturation mixing ratios along back trajectories are given by green (10-day trajectories) and red (30-day trajectories) crosses (freeze-drying along the trajectories to $\left.\mathrm{RH}_{\mathrm{ice}}=100 \%\right)$. The green and red dashed lines indicate the average cold point altitude along the back trajectories The right side of each panel displays the fraction of trajectories (binning also for $\theta$ intervals of $2 \mathrm{~K}$ ), along which the minimum saturation is lower (solid magenta line) or higher (dashed-dotted magenta line) by 0.5 ppmv than the measured mixing ratio. The black solid line represents the fraction of trajectories which have passed the cold point during the last 30 days.

the likelihood to encounter very low temperature regions increases with trajectory length. Second, due to the diabatic ascent of air, a larger part of the trajectories ending in the low stratosphere has passed the cold point region when a longer trajectory history is considered. The horizontal dashed lines denote the mean altitude of the cold point along the backward trajectories (green/red for 10/30-day backward trajectories). In the right side of each panel, the fraction of trajectories which originate from the $380 \mathrm{~K}$ isentrope or below (black line) is displayed. Further, we show the fraction of trajectories whose minimum saturation mixing ratio is higher by $0.5 \mathrm{ppmv}$ than the corresponding FISH measurement (magenta solid line) or lower by $0.5 \mathrm{ppmv}$ (dashed-dotted magenta line), respectively.

For SCOUT-O3 (Fig. 4a), the average of the FISH data is consistent with the trajectory history from approximately 375 to $405 \mathrm{~K}$. The trajectory length has only a small influence. This implies, that air masses are dehydrated locally or near-by in the same region over this rather large altitude range. A more detailed analysis of the freeze-drying evolution over the SCOUT-O3 period around the cold point and its modulation by Kelvin waves is given by Brunner and Schiller (2009). Further, additional injections of water to these altitudes (see Sect. 4.2) can be freeze-dried back to these low values. Higher up in the stratosphere, the measured $\mathrm{H}_{2} \mathrm{O}$ data are much lower than the recent saturation along the trajectories. Thus, their water vapour set point goes back to earlier seasons, and the fraction of trajectories that have passed the cold point tropopause within the last month is close to zero for $\theta>410 \mathrm{~K}$.
Below $380 \mathrm{~K}$, measured FISH data are however higher than the minimum saturation mixing ratio along the back trajectories. This implies that the potentially dry air should have been moistened recently - most likely by deep convection which occurred quite frequently in the operational area (Brunner et al., 2009). But also higher up, i.e. up to $\theta=420 \mathrm{~K}$, a fraction of $10-50 \%$ of the trajectories infers a water mixing ratio lower than the observation by at least $0.5 \mathrm{ppmv}$ (magenta dashed-dotted line), indicative for moistening of the lowermost stratosphere by overshooting convection (see Sect. 4.2), or ECMWF temperatures being too low.

For TroCCiNOx (Fig. 4b), a large change of the saturation mixing ratio along the backward trajectories is evident when increasing their length from 10 to 30 days. The 30-day trajectories are by far closer to the low observed values at 375 $400 \mathrm{~K}$ than the shorter ones. This implies, that the set point of the low water vapour at these altitudes dates back up to a month and likely from a remote region (see Sect. 4.1.2). The reported frequent subsaturation close to the cold point and above (Fig. 2b) already showed that the operational area at the edge to the subtropics is not an area of active dehydration - at least when air with low mixing ratios is advected. Below $380 \mathrm{~K}$, again a large fraction of trajectories ( 30 day only) implies a lower $\mathrm{H}_{2} \mathrm{O}$ mixing ratio than the observations show. Again, deep convection is one source of recent injections up to the cold point, in few cases even above (e.g. Chaboureau et al., 2007). In the vicinity of the subtropical jet, however also mixing with extratropical and tropospheric air is an efficient source of additional water, as demonstrated in case studies for the TroCCiNOx data (Konopka et al., 2007). 

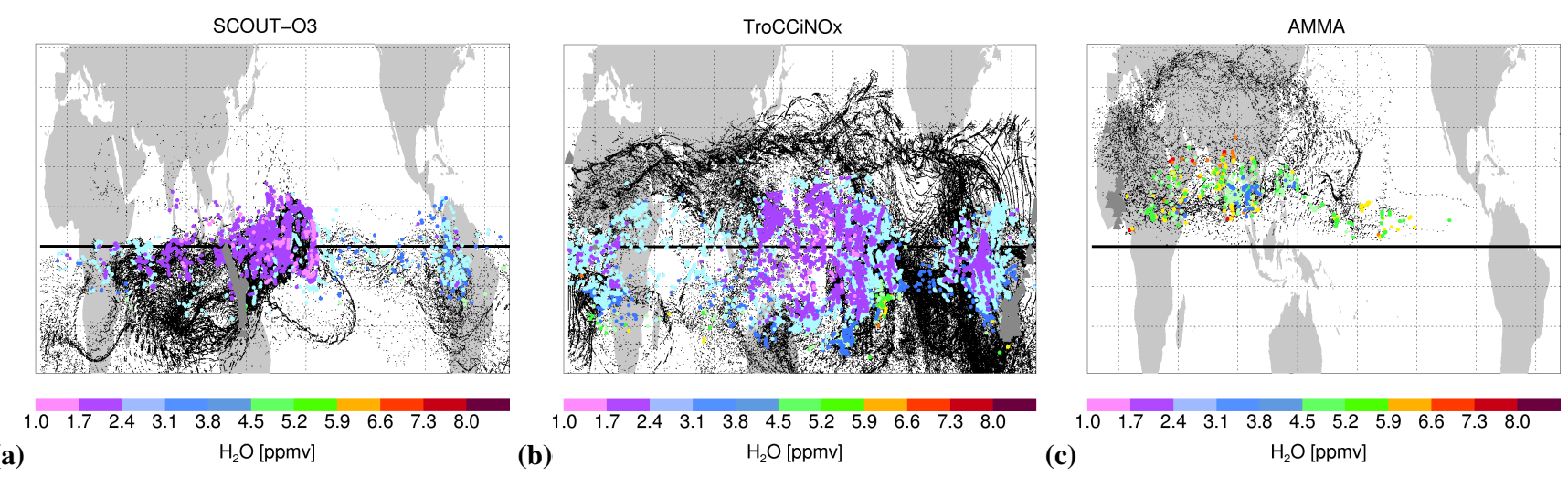

Fig. 5. Location of coldest temperatures along backward trajectories $(\theta=375-410 \mathrm{~K})$ with end points along the flight tracks during (a) SCOUT-O3, (b) TroCCiNOx and (c) AMMA/SCOUT-O3 (considered flight routes including part of the transfers displayed by grey triangles). The minimum saturation mixing ratio along the backtrajectories if corresponding to the aircraft measurement is marked in colour.

For the AMMA/SCOUT-O3 observations (Fig. 4c), saturation along the backward trajectories can explain the $\mathrm{H}_{2} \mathrm{O}$ measurements only up to the cold point around $370 \mathrm{~K}$. Even the minimum saturation over 30 days does not approach the measurements much closer in the stratosphere anymore. In the TTL, the much higher temperatures result in much higher saturation mixing ratios than for the other two campaigns. The observations are closer to this value; the slight enhancement is again indicative for moistening by convection. There is however also a small fraction of trajectories, which end at higher observed $\mathrm{H}_{2} \mathrm{O}$ mixing ratios than expected from the temperature history (magenta dashed-dotted line). We discuss in Sect. 4.2 that also over Africa convection penetrating the tropopause is moistening the lowest layers of the stratosphere. It is worth to note that the range of trajectories which have passed the cold point (black line at the right) ends below $400 \mathrm{~K}$, consistent with the slower upwelling in this season (e.g. Randel et al., 2007).

\subsubsection{Tropical regions of dehydration}

The backward trajectory calculations are suited to identify the tropical region where saturation at the lowest mixing ratio preferably occurs. Figure 5 shows the cold points along the 30-day backward trajectories for the three campaigns in the potential temperature range $375-410 \mathrm{~K}$, colour-coded for the corresponding minimum saturation mixing ratio if it agrees with the observation within an interval of $\pm 0.5 \mathrm{ppmv}$.

The lowest temperatures for the Darwin measurement (Fig. 5a) occur close to the aircraft tracks in the equatorial Western Pacific. This region has been identified also in previous studies as the tropical region with the highest dehydration potential in this season (e.g. Fueglistaler et al., 2005). The observed low temperatures around Darwin and the frequent observation of high $\mathrm{RH}_{\text {total }}$ at low $\mathrm{H}_{2} \mathrm{O}$ mixing ratios are indicative for active dehydration also in the operational area. Thus, the outflow and overshoots from deep convection with local injection of water from the troposphere (Sect. 4.2) are likely instantaneously freeze-dried back to extremely low mixing ratios.

As discussed above, for TroCCiNOx only saturation along longer trajectories can explain the observed low mixing ratios over Southern Brazil. The air masses probed by the aircraft have been dried in regions more equatorwards (Fig. 5b), in particular over South America and over the Western and Central Pacific during the preceding 30 days. Also the ECMWFbased climatology compiled by Fueglistaler et al. (2005) identified these two regions to be coldest. Our measurements at the edge to the subtropics show that the dehydration to lowest mixing ratios at these cold spots is advected also to remote regions with higher temperatures.

For AMMA/SCOUT-O3, the air masses probed over Africa generally origin from the East passing also the Asian monsoon region (Fig. 5c). Lowest temperatures corresponding to a saturation mixing ratio of 4-6 ppmv occur over India and the Gulf of Bengal. Thus, the $\mathrm{H}_{2} \mathrm{O}$ mixing ratios close to the cold point observed over Africa are broadly consistent with the colder set point in the Southern flank of the Asian Monsoon. So the Asian monsoon is not only a major source of water vapour as concluded from previous studies (e.g. Randel and Park, 2006; James et al., 2008), its cold point characteristics at the same location also regulate the entry of water vapour into the stratosphere and determine the water vapour concentrations also in the downwind regions over Africa.

\subsubsection{Trajectory-based reconstruction of $\mathrm{H}_{2} \mathrm{O}$ with HALOE climatological data}

In contrast to the trajectory calculations in Sect. 4.1.1, we now extend the discussion of the saturation history by initialising the trajectory end points with data from the Halogen Occultation Experiment (HALOE) onboard the Upper Atmosphere Research Satellite (UARS). A climatological data set 

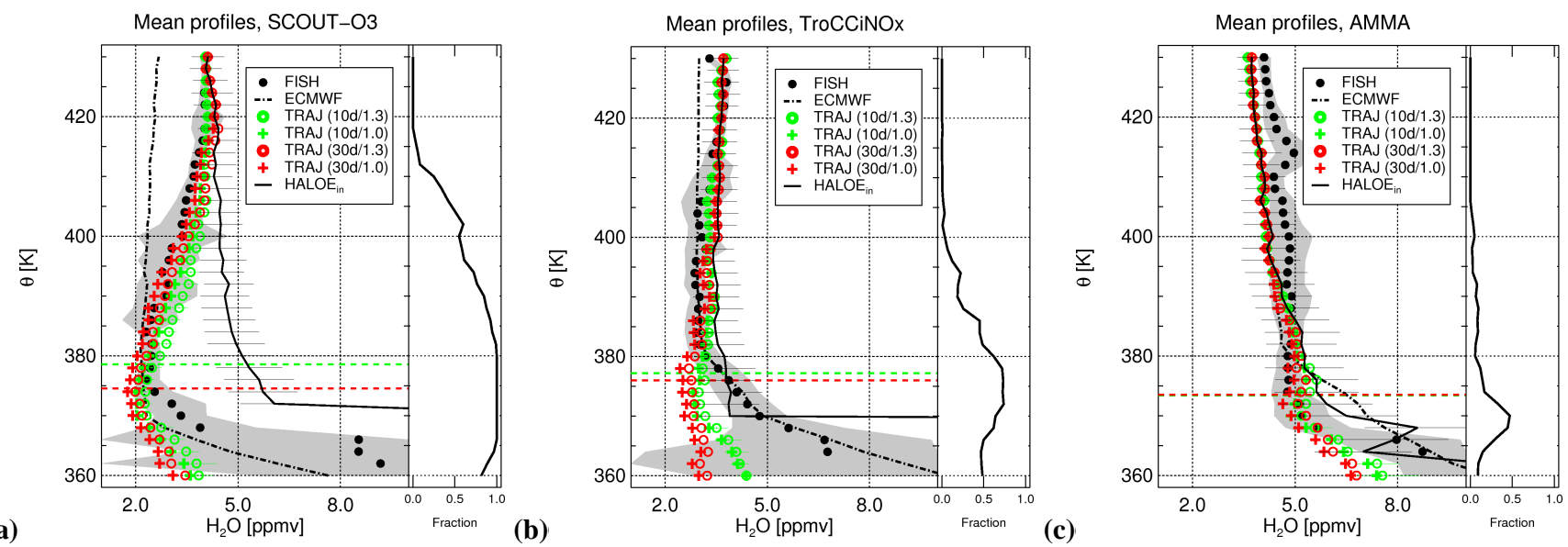

Fig. 6. Comparison between mean measured $\mathrm{H}_{2} \mathrm{O}$ profiles (as in Fig. 4, panels (a)-(c) again display the three campaigns) and simulated ones; freeze-drying along the trajectories to $\mathrm{RH}_{\mathrm{ice}}=100 \%$ (crosses) and $130 \%$ (circles). Here, backtrajectory calculations of the water vapour mixing ratio at the flight route are initialised with $\mathrm{H}_{2} \mathrm{O}$ climatological data from the HALOE satellite experiment (green dots based on 10day trajectories, red dots on 30-day trajectories). The black profiles show the mean HALOE profiles and their standard deviation used for initialisation of the trajectory calculations. The dashed-dotted profile is the averaged ECMWF specific humidity value interpolated to the flight tracks. The right subpanels show the fraction of trajectories along which a cold point below the HALOE initial value is encountered.

of $\mathrm{H}_{2} \mathrm{O}$ of this experiment is compiled for the years 1991 to 2002 in Grooß and Russell (2005). For the initialisation, the zonal average for the respective latitude bin at the backward trajectory end point is chosen. Figure $6 a-c$ shows in analogy to Fig. 4 the HALOE-initialised water vapour profiles after modifications by 10-day and 30-day backward trajectory calculations (green and red dots, respectively), compared to the actually measured FISH data for the three tropical campaigns. The simulations are done for $\mathrm{RH}_{\text {ice }}$ of $100 \%$ (crosses) and $130 \%$ (circles). The black line in the main panels denotes the mean HALOE climatological $\mathrm{H}_{2} \mathrm{O}$ profile used for initialisation.

For SCOUT-O3 (Fig. 6a), the change between the HALOE initialisation profile (black line) and the reconstructed mixing ratios at the observation point (green and red dots, for trajectory lengths of 10-day and 30-day, respectively) is largest. The large modifications below $410 \mathrm{~K}$ are already expected from the discussion in Sect. 4.1.1, as the cold point is frequently reached along the trajectories, also in the lower stratosphere: The fraction of trajectories along which a cold point below the HALOE initial value is encountered, is $100 \%$ to $10 \%$ in the $\theta$-range $380-410 \mathrm{~K}$ (right subpanel). Above the cold point, the calculated $\mathrm{H}_{2} \mathrm{O}$ profiles (30-day trajectories) match extremely well the mean profiles measured by FISH, and those for the shorter 10-day history are only slightly higher. Below the cold point, recent convection has enhanced the actual $\mathrm{H}_{2} \mathrm{O}$ mixing ratio compared to the simulated values, as already discussed above.

The TroCCiNOx comparison provides also a good agreement between the reconstructed and measured $\mathrm{H}_{2} \mathrm{O}$ mean profiles above $\theta=380 \mathrm{~K}$ (Fig. 6b). Here, the modifications between the climatological HALOE profiles along the trajectories are by far weaker than for the SCOUT-O3 period, i.e. only $50 \%$ to $10 \%$ of the trajectories at $380-400 \mathrm{~K}$ meet a cold point below the HALOE initial value (right subpanel). Below $380 \mathrm{~K}$, the measured mean $\mathrm{H}_{2} \mathrm{O}$ mixing ratio is higher than the reconstructed value, indicative for additional recent moistening (see Sect. 4.1.1) due to vertical mixing along the subtropical jet (Konopka et al., 2007).

For AMMA/SCOUT-O3 (Fig. 6c), virtually no change of the initial HALOE profile occurs along the back trajectories above $375 \mathrm{~K}$. Here, the slope of the profiles is very similar, though the HALOE climatological data are lower by approximately $0.4 \mathrm{ppmv}$ (or $10 \%$ ) above $390 \mathrm{~K}$. Good agreement is found at $370-390 \mathrm{~K}$, while below the measurements are again higher than the simulations, as for the other campaigns.

The systematic difference between the reconstructions, based on HALOE data, and the FISH profiles in the stratosphere during AMMA/SCOUT-O3 is likely caused by instrument uncertainties. In a comprehensive comparison of HALOE data with in-situ instruments (Kley et al., 2000), HALOE measurements of $\mathrm{H}_{2} \mathrm{O}$ were found at the low end compared to other hygrometers. In particular, FISH and HALOE data differed by about $8 \%$, which is almost the same discrepancy we find in the AMMA/SCOUT-O3 data again. We note that this discrepancy is within the uncertainty of both instruments, and Kley et al. (2000) did not assign one single instrument as the absolute reference for atmospheric water measurements. However, also in other studies HALOE data appeared to be lower than measurements from other reference instruments. If we assume a low bias of the HALOE measurements on the order of $8 \%$, the agreement between the simulations and FISH measurements would improve for the AMMA/SCOUT-O3 case. Initialisation with 
higher HALOE data would however not change the $\mathrm{H}_{2} \mathrm{O}$ reconstruction for TroCCiNOX and SCOUT-O3 to a larger extent, as most of these data are lowered to the saturation mixing ratio at the minimum cold point along the back trajectories anyway. Therefore, our tropical measurements may be a confirmation for the previously found moderate low bias of HALOE data compared to FISH measurements. As noted already in Sect. 3, mean FISH profiles agree also well with those of the AMMA balloon data using the FLASH-B hygrometer (Khaykin et al., 2009), the slight discrepancy at $19-20 \mathrm{~km}$ of $0.2 \mathrm{ppmv}$ is even lower than the total accuracy of the instruments implies (approx. 8\% for FISH and 10\% for FLASH-B).

Beside such potential systematic instrument discrepancies, a deviation of our FISH measurements from simulations using a climatological initialisation may also be caused by atmospheric variability - in particular for the AMMA/SCOUT$\mathrm{O} 3$ case when the $\mathrm{H}_{2} \mathrm{O}$ concentration is not altered along the back trajectories for a large altitude range. Randel et al. (2004a) discussed, inter alia based on HALOE data, interannual changes of stratospheric water vapour which could be attributed to changes of temperatures at the tropical tropopause associated with the quasi-biennial oscillation (QBO) and El Niño-Southern oscillation. Hereby, $\mathrm{H}_{2} \mathrm{O}$ anomalies on the order of a few tenths ppmv are observed, which are of the same order of magnitude as the observed discrepancies during AMMA/SCOUT-O3. After the unexpected drop of water vapour entry around 2001 (e.g. Randel et al., 2006), recent satellite observations (Jones et al., 2009) indicate that water vapour in the tropical lower stratosphere has approached values for our observation period in 2005/2006 which are comparable to the mean values of the period considered in the HALOE climatology of Grooß and Russel (2005). In summary, the observed discrepancies between HALOE and FISH data during AMMA/SCOUT-O3 in the stratosphere may be caused by the interannual variability of water vapour entry, though there is no quantitative assessment of such an effect possible for the moment. Support for the attribution of the low SCOUT-O3 measurements in Darwin to low variability is given by the balloon soundings in Indonesia in January 2006 which showed indeed lower water vapour profiles than in the following years (H. Vömel, personal communication, 2009).

Zonal asymmetry may also have caused the observed discrepancies during AMMA/SCOUT-O3. In extension of the HALOE climatology by Grooß and Russel (2005), Fig. 7 shows the zonal distribution of $\mathrm{H}_{2} \mathrm{O}$ averaged for $0-15^{\circ}$ in August derived from HALOE measurements for the years 1992-2005 as well as the deviation from the zonal mean. We note that with the resolution of $24^{\circ}$-latitude bins (i.e. according to the HALOE orbits) only 5-30 data points contribute per bin, despite the large HALOE data set. Therefore, the significance in particular for the lower isentropes is limited. The increased mixing ratios above Africa (peak at $0^{\circ}$ longitude) and Asia (peak at $100^{\circ} \mathrm{E}$ longitude) imply an influence
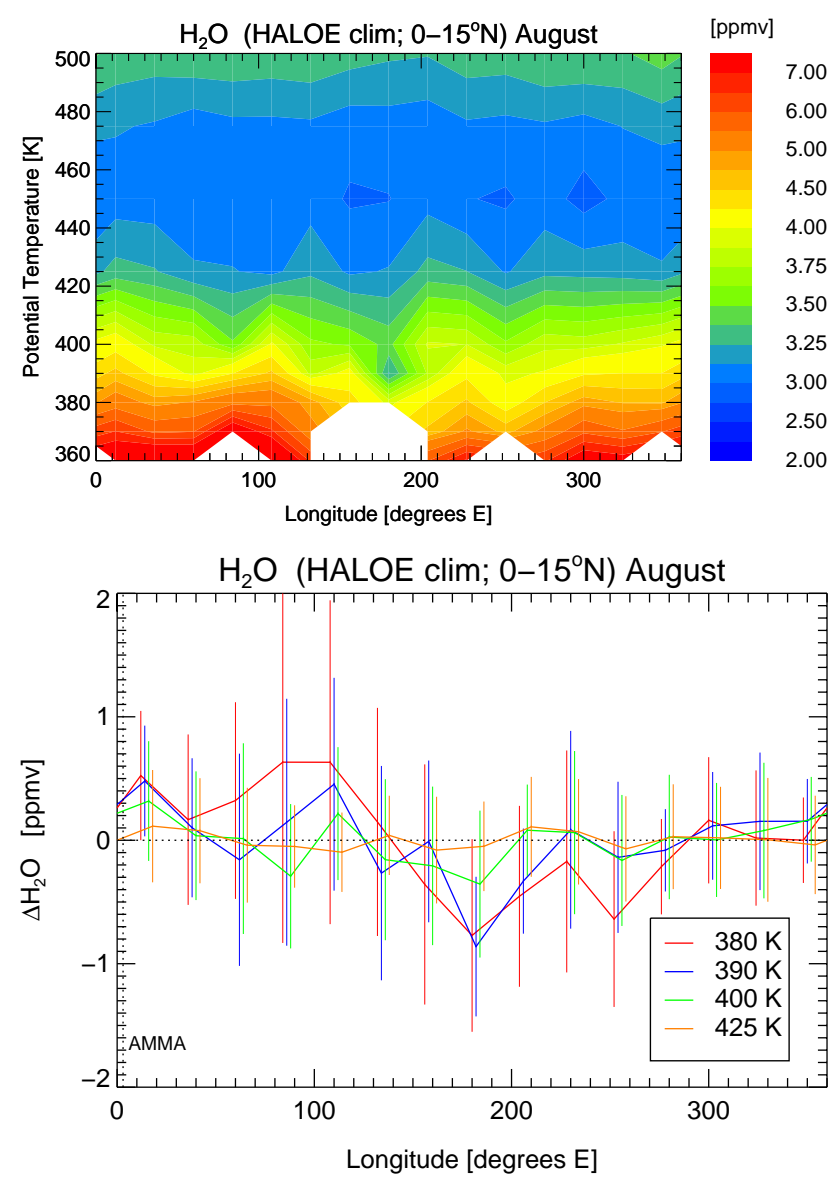

Fig. 7. HALOE climatology of $\mathrm{H}_{2} \mathrm{O}$ at $0-15^{\circ} \mathrm{N}$ for August of years 1992-2005 as function of longitude constructed similar as in Grooß and Russel (2005) (upper panel) and deviations from the mean at four different isentropes (lower panel).

of the monsoon regions on the TTL. They are strongest at $380 \mathrm{~K}$ close to the cold point region with up to $0.5 \mathrm{ppmv}$ for the Asian monsoon region. The zonal modulation is weakened with increasing altitude to an amplitude of $0.1 \mathrm{ppmv}$ at $425 \mathrm{~K}$, close to the altitude where our data set still see sporadically enhanced $\mathrm{H}_{2} \mathrm{O}$ layers (Sect. 4.2), and almost vanishes above. From the climatological HALOE perspective, the influence of the monsoon regions is apparent but limited to a few tenths of ppmv in the TTL above the cold point, i.e. 39\% additional water compared to the zonal mean. Hereby, the direct contribution of the African monsoon might still be overestimated as this region is located downwind of the Asian monsoon input region.

In summary, the HALOE-initialised reconstruction of water shows good agreement with the SCOUT-O3 and TroCCiNOx data. The frequent dehydration events in the trajectory history explain why the regionally observed data differ significantly from the initial, climatological satellite profiles. For AMMA/SCOUT-O3, the initial HALOE profile remains almost unchanged in the stratosphere by the reconstruction. 
The known bias between HALOE and FISH is sufficient to explain the observed discrepancies of about $10 \%$. Comparisons of climatological data with regional ones in a specific year allow us to estimate an upper limit of the possible impact of phenomena which are not considered in the reconstruction, in particular that of local convection (Sect. 5).

For comparison, the specific humidity from ECMWF SHECMWF interpolated to the flight route is plotted in Fig. 6a-c (dashed-dotted black lines). For the SCOUT-O3 averages (panel a), SHECMWF and FISH profiles agree well up to $380 \mathrm{~K}$ potential temperature. In the stratosphere SHECMWF has a low bias by $1-2$ ppmv compared to both the FISH data and the reconstructed $\mathrm{H}_{2} \mathrm{O}$, and the slope is less steep than that of the observations. For the TroCCiNOx campaign (Fig. 6b), the discrepancies between FISH measurements and SHECMWF are qualitatively very similar as during SCOUT-O3, but somewhat lower in magnitude. During AMMA/SCOUT-O3, SHECMWF is again lower than the FISH profile in stratosphere and thus matches the reconstructed water; around the cold point, SHECMWF exceeds the observations. As a general tendency, SHECMWF underestimates the measured $\mathrm{H}_{2} \mathrm{O}$ mixing ratios in the stratosphere by $0.5-2$ ppmv, with larger discrepancies at higher altitudes. Similar differences between matched HALOE/MLS data and SHECMWF (ERA-40 analysis) are also apparent in a zonal mean climatology (Dethof, 2003; Fig. 3 therein), i.e. a larger bias and less steep gradients of SHECMWF compared to the satellite zonal mean data for the tropical SH in January and a somewhat better agreement for the AMMA/SCOUTO3 latitudes and season at higher mixing ratios. Comparing the water tape recorder of ECMWF products and that of the HALOE climatology (not shown), a too effective vertical transport rate in ECMWF assimilations seems to be the main reason for the discrepancy between SHECMWF and observations.

\subsection{Moistening by deep convection}

In Sect. 4.1, we concluded that the major outflow of convection below the cold point results in a moistening of the lower TTL. However, this additional water vapour does not result in an increased transport of $\mathrm{H}_{2} \mathrm{O}$ into the stratosphere, as it is trapped at the cold point during the subsequent ascent. As an example, observations in the aged outflow of a strong Hector event on 30 November 2005 showed saturated air masses over a large area at and below the cold point at mixing ratios of 2-4 ppmv with only a few remnants of particle plumes. Therefore, already a few hours after a convective event, the air masses from the outflow might be freeze-dried back to the saturation conditions.

Figure 2 however shows layers of significantly enhanced water up to $420 \mathrm{~K}$ in several profiles of all three campaigns, which are indicative of convective overshoots. In Schiller et al. (2008), we determined ice water content (IWC) of these ice clouds from the Darwin and Brazilian experiments. IWC in these clouds at the top of deep convection can be up to tens of ppmv and is thus significantly higher than the climatological range of IWC from other observations at these low temperatures (Plate 8 in Schiller et al., 2008) and the ambient mixing ratio. Such high IWC are therefore indicative of rapid transport from the troposphere as in convection. Previously, Kelly et al. (1993) reported observations of particles above $400 \mathrm{~K}$ above Hector storms, however with IWC lower than 2 ppmv. Corti et al. (2008) and de Reus et al. (2009) showed that our measurements of enhanced water are correlated with particle measurements, in several cases with diameters of $40 \mu \mathrm{m}$ and above. In the Corti et al. (2008) study, hypotheses other than convective origin of these particles could be excluded. The observations provide evidence that these particles injected above the cold point have a moistening effect and that vice versa, there is no indication for a "convective dehydration" as proposed in previous studies (Danielsen, 1993; Sherwood and Dessler, 2000). They confirm model calculations by Jensen et al. (2007) postulating such a moistening effect if particles are injected in subsaturated air above the tropopause.

Dynamical tracers as $\mathrm{CO}$ and $\mathrm{O}_{3}$ measured simultaneously do not show coincidental features in the layers of enhanced $\mathrm{H}_{2} \mathrm{O}$ and particles (S. Vicciani and F. Ravegnani, personal communications, 2007). These observations indicate that the fraction of in-mixed air from the troposphere is too small to be detected in these tracers, but is visible in $\mathrm{H}_{2} \mathrm{O}$ due to the large concentration gradient.

The measurements over Africa also show layers of enhanced water up to $420 \mathrm{~K}$ in single profiles (Fig. 2c). In contrast to the observations during SCOUT-O3 and TroCCi$\mathrm{NOx}$, these measurements were not obtained in the vicinity of deep convection and no particles are detected in these layers (except a very moderate enhancement of backscatter ratio in the multi-angle spectrometer on 8 August 2006; F. Cairo personal communication, 2009). On the other hand, back trajectory calculation show that these observations were made downwind of large mesoscale convective systems detected with good coincidence in time and location by the Meteosat08 observations (CLaMS trajectories, not shown). Even if overshoots into the stratosphere may not be fully resolved by cloud top heights derived using brightness temperature differences, they have likely occurred above the identified deep convective systems underlying. These observations, which are similar to those reported from AMMA balloon-borne measurements in the same region (Khaykin et al., 2009), provide evidence that deep convection injects water irreversibly above the cold point, as these layers with $\mathrm{H}_{2} \mathrm{O}$ enhanced by 2-3 ppmv can still be detected about $10-20 \mathrm{~h}$ after the convective event in subsaturated air without remnants of particles. Therefore, we can exclude that such injections occur only as a temporary lifting above the tropopause without mixing with the environment as well as a complete sedimentation of particles back to tropospheric altitudes. 
The observed layers with enhanced water vapour above the cold point are a highly localised phenomenon on horizontal scales of several $10 \mathrm{~km}$. Probing these events above Tiwi Island during SCOUT-O3, identified an area on the order of $2000 \mathrm{~km}^{2}$ (50 km diameter) with particles above the tropopause. Similarly, during AMMA the layers occurred only in single profiles while the next profile a few $100 \mathrm{~km}$ apart showed again the undisturbed background profile. The observations during the three campaigns, also taking into account the balloon observations by Khaykin et al. (2009), are quite frequent for such a small-scale phenomenon. On the other hand, its fraction of the total number of measured profile has to be regarded as a biased upper limit, since the flight programme in all missions was focused on the observation of convective systems and their outflow regions.

\section{Conclusions}

The three tropical airborne campaigns discussed in this study yield different but complementary information on the water vapour distribution and related processes in the TTL. The measurements during SCOUT-O3 from Darwin, Australia in November and December 2005 were characterised by lowest temperatures and mixing ratios close to the cold point. Frequent cloud occurrence, high relative humidity and backward trajectory calculations demonstrated that in the operational area and nearby regions efficient dehydration down to lowest mixing ratios of less than 2 ppmv occurs. During TroCCiNOx over Southern Brazil in February 2005, almost the same low mixing ratios were observed but at lower $\mathrm{RH}_{\text {total }}$. The freeze-drying events had occurred several weeks before in cold regions equatorwards. The AMMA/SCOUT-O3 mission from West Africa in August 2006 showed a completly different mean water profile with higher mixing ratios in the TTL according to the season. The region is strongly influenced by air masses from the Asian monsoon region, which also appeared to be the region determining the mean water vapour abundance observed. Though the observations of water vapour are highly variable between the three campaigns and even between single flights of one mission, they allow for a consistent interpretation towards a conclusive understanding of water vapour transport and transformation through the TTL into the stratosphere.

From our data, the tropical water vapour entry into the stratosphere is found to be a highly complex interplay between freeze-drying in the coldest regions of the TTL and fresh supply of water by convection or by mixing with tropospheric air. Based on our studies, the $420 \mathrm{~K}$ isentrope appears to be the transition between a regionally controlled regime and a zonally well mixed compartment at higher altitudes. This is a quantitative confirmation of the TTL concept discussed in Fueglistaler et al. (2009). It coincides with the highest altitude of direct impact of overshooting convection. Further, recent condensation and sedimentation of particles may have altered the composition below $420 \mathrm{~K}$ leading to regional deviations from the zonal mean. Though an interannual variability of the TTL parameters has been observed to propagate further up and is visible in the different tape recorder signals, the local and regional variability in the TTL becomes smeared out above $420 \mathrm{~K}$.

The main outflow of convection below the cold point as well as frequently observed local overshoots into the stratosphere have been unequivocally identified to moisten their environment. Below the tropopause, our measurements show significantly higher $\mathrm{H}_{2} \mathrm{O}$ mixing ratios than inferred from the backtrajectory history which does not consider recent individual convective systems. However, no significant remnants of this high water released in the lower TTL can be found above the cold point anymore as this additional water is removed on its way through the cold point.

Further, we found layers of enhanced water vapour above the cold point which could be traced to direct injection by overshooting turrets. These irreversible injections of $\mathrm{H}_{2} \mathrm{O}$ up to $420 \mathrm{~K}$ were observed to be isolated and thus highly localised, i.e. with horizontal extensions on the order of $50 \mathrm{~km}$. Even if an estimate of the amount of water injected in such a single event is possible (Chemel et al., 2009), an upscaling of its global impact on the stratospheric water vapour budget might be possible only with large uncertainties (Corti et al., 2009). A global distribution of convection penetrating the tropopause has been derived from satellite data (Gettelman et al., 2002; Liu and Zipser, 2005). Our high resolution measurements confirm the maximum depth of $1.5 \mathrm{~km}$ above the cold point as found in these studies. Based on a brightness temperature analysis of satellite cloud data, Gettelman et al. (2002) estimated a zonal mean fraction area of $0.1 \%$ of convection penetrating the tropopause, while the TRMM data analysis of Liu and Zipser results in a still lower frequency. The difference, also apparent in the geographical distribution, is likely caused by biases of the different data and their retrieval. However, the regions and seasons we investigated during SCOUT-O3, TroCCiNOx and AMMA/SCOUT-O3 are identified in both studies to be representative for intensive deep convective activity; other key regions are the Western Pacific, the Congo basin, the Indian monsoon region and Central America (Panama region).

The comparison of our data with the HALOE-initialised reconstruction of $\mathrm{H}_{2} \mathrm{O}$ could however give a hint on the maximum possible impact of overshoots on the stratospheric water vapour budget. For SCOUT-O3 and to a lesser extent also for TroCCiNOx conditions, additional water injected above the cold point can still be freeze-dried to the low mean values there. The comparison of the AMMA/SCOUT-O3 data with the climatological HALOE profile might suggest enhanced water vapour abundance over Africa (Fig. 6c). Most likely, the observed discrepancy however reflects the formerly identified low bias of HALOE compared to FISH data, in particular as the offset ranges to higher altitudes than the highest observed overshoots. An effect by interannual variability may 
be on the order of 10\% difference (Sect. 4.1.3) and could depending on its sign - mask a potentially larger discrepancy between our data and the climatology for this particular year. From the comparison between the HALOE-based water reconstruction and the AMMA/SCOUT-O3 data set we might not be able to quantify precisely the convective impact on the lower stratospheric water content, as there are several remaining uncertainties. On the other hand, based on the magnitude of these uncertainties we do not find evidence for an enhancement of $\mathrm{H}_{2} \mathrm{O}$ over Africa of more than $10 \%$. Zonal asymmetries in the HALOE climatological data (Fig. 7) imply such an increase over the African monsoon region and therefore corroborate the finding of a potential moistening of the TTL up to $420 \mathrm{~K}$ - but only to a moderate degree.

Trajectory-based reconstruction of water vapour, initialised with climatological HALOE data, yield a remarkable agreement with the in-situ observations presented in this study above the tropopause for the different regions and seasons studied. Therefore the Lagrangian saturation history on time scales of hours to 1 month appears to be appropriate and sufficient to describe the average $\mathrm{H}_{2} \mathrm{O}$ distribution at the cold point tropopause and in the first kilometres above. The moderate warm bias of the ECMWF analysis compared to radio sonde data may underestimate the drying of air as it enters the stratosphere.

So, our results confirm previous findings from similar Lagrangian studies (e.g. Fueglistaler et al., 2005; Fueglistaler and Haynes, 2005), however now demonstrated with a data set of much finer scales in time and space and thereby covering different tropical regions and seasons. Jensen and Pfister (2004) tested with a more sophisticated Lagrangian ice cloud model the sensitivity of the stratospheric vapour entry on cloud properties and their dependence on wave perturbations and other parameters. While cloud frequency and distribution depended sensitively on these parameters, they also concluded that final water vapour mixing ratios are primarily controlled by the minimum temperatures encountered.

Also studies with a Eulerian model showed that the stratospheric input of water vapour is largely controlled by largescale transport across the cold tropical tropopause (Lelieveld et al., 2007). In their study similar to ours, convection moistens the TTL, but deep overshooting convection penetrating into the stratosphere does not play a significant role in the stratospheric water budget.

Our results confirm these studies and thereby the preceding ideas of Holton and Gettelman (2001) with new experimental evidence, that despite the complex interplay of various processes leading to a highly variable water distribution in the tropics, stratospheric water vapour entry is primarily controlled by the coldest regions in the TTL, in which the air is freeze-dried to its final set point during its way into the stratosphere. The successful trajectory-based reconstruction of $\mathrm{H}_{2} \mathrm{O}$ above the tropopause is first of all determined by the reliability of the horizontal wind fields and the temperature distribution, though convection is only insufficiently parameterized in the underlying ECMWF meteorological data. It is therefore unlikely, that the individually observed deep convective events have a major impact on the global water budget above the tropopause.

Acknowledgements. Discussion of the results and developing ideas of their meaning with many members of the project teams of SCOUT-O3, TroCCiNOx and AMMA/SCOUT-O3 is gratefully acknowledged. We thank MDB, DLR and ERS-Ltd operating and managing the aircraft under the challenging tropical conditions. The study was primarily conducted under the SCOUT-O3 Integrated Project (EC Contract GOCE-CT-2004-505390), with additional campaign funding by the EC projects TroCCiNOx and AMMA as well as by INSU and the Geophysica EEIG.

Edited by: N. Harris

\section{References}

Brunner, D., Siegmund, P., May, P. T., Chappel, L., Schiller, C., Müller, R., Peter, T., Fueglistaler, S., MacKenzie, A. R., Fix, A., Schlager, H., Allen, G., Fjaeraa, A. M., Streibel, M., and Harris, N. R. P.: The SCOUT-O3 Darwin Aircraft Campaign: rationale and meteorology, Atmos. Chem. Phys., 9, 93-117, 2009, http://www.atmos-chem-phys.net/9/93/2009/.

Brunner, D. and Schiller, C.: Large fluctuations of tropopause moisture over the Maritime Continent induced by a Kelvin wave during the SCOUT-O3 campaign in Darwin, Australia, Atmos. Chem. Phys. Discuss., in preparation, 2009.

Cairo, F., Pommereau, J. P., Law, K. S., Schlager, H., Garnier, A., Fierli, F., Ern, M., Streibel, M., Arabas, S., Borrmann, S., Berthelier, J. J., Blom, C., Christensen, T., D’Amato, F., Di Donfrancesco, G., Deshler, T., Diedhiou, A., Durry, G., Engelsen, O., Goutail, F., Harris, N. R. P., Kerstel, E. R. T., Khaykin, S., Konopka, P., Kylling, A., Larsen, N., Lebel, T., Liu, X., MacKenzie, A. R., Nielsen, J., Oulanowski, A., Parker, D. J., Pelon, J., Polcher, J., Pyle, J. A., Ravegnani, F., Rivière, E. D., Robinson, A. D., Röckmann, T., Schiller, C., Simões, F., Stefanutti, L., Stroh, F., Some, L., Siegmund, P., Sitnikov, N., Vernier, J. P., Volk, C. M., Voigt, C., von Hobe, M., Viciani, S., and Yushkov, V.: An overview of the SCOUT-AMMA stratospheric aircraft, balloons and sondes campaign in West Africa, August 2006: rationale, roadmap and highlights, Atmos. Chem. Phys. Discuss., 9, 19713-19781, 2009,

http://www.atmos-chem-phys-discuss.net/9/19713/2009/.

Chaboureau, J.-P., Cammas, J.-P., Duron, J., Mascart, P. J., Sitnikov, N. M., and Voessing, H.-J.: A numerical study of tropical crosstropopause transport by convective overshoots, Atmos. Chem. Phys., 7, 1731-1740, 2007,

http://www.atmos-chem-phys.net/7/1731/2007/.

Chemel, C., Russo, M. R., Pyle, J. A., Sokhi, R. J., and Schiller, C.: Quantifying the imprint of a severe Hector thunderstorm during ACTIVE/SCOUT-O3 onto the water content in the upper troposphere/lower stratosphere, Mon. Weather Rev., 137, 2493-2514, doi:101175/2008MWR2666.1, 2009.

Corti, T., Luo, B. P., Peter, T., Vömel, H., and Fu, Q.: Mean radiative energy balance and vertical mass fluxes in the equatorial 
upper troposphere and lower stratosphere, Geophys. Res. Lett., 32, L06802, doi:10.1029/2004GL021889, 2005.

Corti, T., Luo, B. P., deReus, M., Brunner, D., Cairo, F., Mahoney, M. J., Matucci, G., Matthey, R., Mitev, V., dos Santos, F. H., Schiller, C., Shur, G., Sitnikov, N. M., Spelten, N., Vössing, H. J., Borrmann, S., and Peter, T.: Unprecedented evidence for overshooting convection hydrating the tropical stratosphere, Geophys. Res. Lett., 35, L10810, doi:10.1029/2008GL033641, 2008.

Danielsen, E. F.: In situ evidence of rapid, vertical, irreversible transport of lower tropospheric air into the lower tropical stratosphere by convective cloud turrets and by larger-scale upwelling in tropical cyclones, J. Geophys. Res., 98, 8665-8681, 1993.

de Reus, M., Borrmann, S., Bansemer, A., Heymsfield, A. J., Weigel, R., Schiller, C., Mitev, V., Frey, W., Kunkel, D., Kürten, A., Curtius, J., Sitnikov, N. M., Ulanovsky, A., and Ravegnani, F.: Evidence for ice particles in the tropical stratosphere from insitu measurements, Atmos. Chem. Phys., 9, 6775-6792, 2009, http://www.atmos-chem-phys.net/9/6775/2009/.

Dethof, A.: Aspects of modelling and assimilation for the stratosphere at ECMWF, available via: www.atmosp.physics. utoronto.ca/SPARC/News21/21_Dethof.html, SPARC newsletter 21, 2003.

Fueglistaler, S., Bonazzola, M., Haynes, P. H., and Peter, T.: Stratospheric water vapour predicted from the Lagrangian temperature history of air entering the stratosphere in the tropics, J. Geophys. Res., 110, D08017, doi:10.1029/2004JD005516, 2005.

Fueglistaler, S. and Haynes, P. H.: Control of interannual and longer-term variability of stratospheric water vapor, J. Geophys. Res., 110, D24108, doi:10.1029/2006JD007273, 2005.

Fueglistaler, S., Dessler, A. E., Dunkerton, T. J., Folkins, I., Fu, Q., and Mote, P. W.: Tropical tropopause layer, Rev. Geophys., 47, RG1004, doi:10.1029/2008RG000267, 2009.

Gettelman, A., Salby, M. L., and Sassi, F.: Distribution and influence of convection in the tropical tropopause region, J. Geophys. Res., 107(D10), 4080, doi:10.1029/2001JD001048, 2002.

Grooß, J.-U. and Russell III, J. M.: Technical note: A stratospheric climatology for $\mathrm{O}_{3}, \mathrm{H}_{2} \mathrm{O}, \mathrm{CH}_{4}, \mathrm{NO}_{x}, \mathrm{HCl}$ and $\mathrm{HF}$ derived from HALOE measurements, Atmos. Chem. Phys., 5, 2797-2807, 2005 ,

http://www.atmos-chem-phys.net/5/2797/2005/.

Grosvenor, D. P., Choularton, T. W., Coe, H., and Held, G.: A study of the effect of overshooting deep convection on the water content of the TTL and lower stratosphere from Cloud Resolving Model simulations, Atmos. Chem. Phys., 7, 4977-5002, 2007, http://www.atmos-chem-phys.net/7/4977/2007/.

Holton, J. R. and Gettelman, A.: Horizontal transport and the dehydration of the stratosphere, Geophys. Res. Lett., 28, 2799-2802, 2001.

James, R., Bonazzola, M., Legras, B., Surbled, K., and Fueglistaler, S.: Water vapor transport and dehydration above convective outflow during Asian monsoon, Geophys. Res. Lett., 35, L20810, doi:10.1029/2008GL035441, 2008.

Jensen, E. J., Pfister, L., Ackerman, A. S., Tabazadeh, A., and Toon, O. B.: A conceptual model of the dehydration of air due to freeze-drying by optically thin, laminar cirrus rising slowly across the tropical tropopause, J. Geophys. Res., 106, 1723717252, 2001.

Jensen, E. and Pfister, L.: Transport and freeze-drying in the tropical tropopause layer, J. Geophys. Res., 109, D02207, doi:10.1029/2003JD004022, 2004.

Jensen, E. J., Ackerman, A. S., and Smith, J. A.: Can overshooting convection dehydrate the tropical tropopause layer?, J. Geophys. Res., 112, D11209, doi:10.1029/2006JD007943, 2007.

Jones, A., Urban, J., Murtagh, D. P., Eriksson, P., Brohede, S., Haley, C., Degenstein, D., Bourassa, A., von Savigny, C., Sonkaew, T., Rozanov, A., Bovensmann, H., and Burrows, J.: Evolution of stratospheric ozone and water vapour time series studied with satellite measurements, Atmos. Chem. Phys., 9, 6055-6075, 2009, http://www.atmos-chem-phys.net/9/6055/2009/.

Kelly, K. K., Proffitt, M. H., Chan, K. R., Loewenstein, M., Podolske, J. R., Strahan, S. E., Wilson, J. C., and Kley, D.: Water vapour and cloud water measurements over Darwin during the STEP 1987 tropical mission, J. Geophys. Res., 98, 8713-8723, 1993.

Khaykin, S., Pommereau, J.-P., Korshunov, L., Yushkov, V., Nielsen, J., Larsen, N., Christensen, T., Garnier, A., Lukyanov, A., and Williams, E.: Hydration of the lower stratosphere by ice crystal geysers over land convective systems, Atmos. Chem. Phys., 9, 2275-2287, 2009, http://www.atmos-chem-phys.net/9/2275/2009/.

Kley, D., Schmeltekopf, A. L., Kelly, K., Winkler, R. H., Thomson, T. L., and MacFarland, M.: Transport of water through the tropical tropopause, Geophys. Res. Lett., 9, 617-620, 1982.

Kley, D., Russell III, J., Phillips, C., edited by: Gettelman, A., Harries, J., Mote, P., Oltmans, S., Remsberg, E., Rosenlof, K., and Schiller, C.: SPARC Assessment of Water Vapour in the Stratosphere and Upper Troposphere, WCRP-113, WMO/TD No. 1043, SPARC Report No. 2, 2000.

Konopka, P., Günther, G., Müller, R., dos Santos, F. H. S., Schiller, C., Ravegnani, F., Ulanovsky, A., Schlager, H., Volk, C. M., Viciani, S., Pan, L. L., McKenna, D.-S., and Riese, M.: Contribution of mixing to upward transport across the tropical tropopause layer (TTL), Atmos. Chem. Phys., 7, 3285-3308, 2007, http://www.atmos-chem-phys.net/7/3285/2007/.

Koop, T., Luo, B. P., Tsias, A., and Peter, T.: Water activity as the determinant for homogeneous ice nucleation in aqueous solutions, Nature, 406, 611-614, 2000.

Krämer, M., Schiller, C., Afchine, A., Bauer, R., Gensch, I., Mangold, A., Schlicht, S., Spelten, N., Sitnikov, N., Borrmann, S., de Reus, M., and Spichtinger, P.: Ice supersaturations and cirrus cloud crystal numbers, Atmos. Chem. Phys., 9, 3505-3522, 2009, http://www.atmos-chem-phys.net/9/3505/2009/.

Lelieveld, J., Brühl, C., Jöckel, P., Steil, B., Crutzen, P. J., Fischer, H., Giorgetta, M. A., Hoor, P., Lawrence, M. G., Sausen, R., and Tost, H.: Stratospheric dryness: model simulations and satellite observations, Atmos. Chem. Phys., 7, 1313-1332, 2007, http://www.atmos-chem-phys.net/7/1313/2007/.

Liu, C. L. and Zipser, E. J.: Global distribution of convection penetrating the tropical tropopause, J. Geophys. Res., 110, D23104 doi:10.1029/2005JD006063, 2005.

MacKenzie, A. R., Schiller, C., Adriani, A., Beuermann, J., Cairo, F., Corti, T., Gensch, I., Krämer, M., Kröger, C., Lepouchov, B., Lowe, D., Merkulov, S., Mitev, V., Oulanovsky, A., Peter, Th., Ravegnani, F., Rohs, S., Rudakov, V., Salter, P., Stefanutti, L., and Yushkov, V.: The tropopause and hygropause in the equatorial Indian Ocean during February and March 1999, J. Geophys. Res., 111(D18), D18112, doi:10.1029/2005JD006639, 2006. 
May, P. T., Allen, G., Vaughan, G., and Connolly, P.: Aerosol and thermodynamic effects on tropical cloud systems during TWPICE and ACTIVE, Atmos. Chem. Phys., 9, 15-24, 2009, http://www.atmos-chem-phys.net/9/15/2009/.

Mote, P. W., Rosenlof, K. H., McIntyre, M. E., Carr, E. S., Gille, J. C., Holton, J. R., Kinnersley, J. S., Pumphrey, H. G., Russell III, J. M., and Watery, J. W.: An atmospheric tape recorder: The imprint of tropical tropopause temperatures on stratospheric water vapour, J. Geophys. Res., 101, 3989-4006, 1996.

Newell, R. E. and Gould-Stewart, S.: A stratospheric fountain, J. Atmos. Sci., 38, 2789-2796, 1981.

Peter, Th., Luo, B. P., Wirth, M., Kiemle, C., Flentje, H., Yushkov, V. A., Khattatov, V., Rudakov, V., Thomas, A., Borrmann, S., Toci, G., Mazzinghi, P., Beuermann, J., Schiller, C., Cairo, F., Di Donfrancesco, G., Adriani, A., Volk, C. M., Strom, J., Noone, K., Mitev, V., MacKenzie, R. A., Carslaw, K. S., Trautmann, T., Santacesaria, V., and Stefanutti, L.: Ultrathin Tropical Tropopause Clouds (UTTCs): I. Cloud morphology and occurrence, Atmos. Chem. Phys., 3, 1083-1091, 2003,

http://www.atmos-chem-phys.net/3/1083/2003/.

Plöger, F., Konopka, P., Günther, G., Grooß, J.-U., and Müller, R.: Impact of the vertical velocity scheme on modeling transport in the tropical tropopause layer (TTL), J. Geophys. Res., doi:10.1029/2009JD012023, in press, 2009.

Randel, W. J., Wu, F., Oltmans, S., Rosenlof, K., and Nedoluha, G. E.: Interannual changes of stratospheric water vapor and correlations with tropical tropopause temperatures, J. Atmos. Sci., 61, 2133-2148, 2004a.

Randel, W., Uedelhofen, P., Fleming, E., Gelma, M., Hamilton, K., Karoly, D., Ortland, D., Swinbank, R., Chanin, M.-L., Keckhut, P., Labitzke, K., Remsberg, E., Simmons, A., Wu, D., Geller, M., Pawson, S., Wu, F., and Baldwin, M.: The SPARC intercomparison of middle-atmosphere climatologies, J. Climate, 17, 986-1003, doi:10.1175/15200442(2004)017;0986:TSIOMC ¿2.0.CO;2, 2004b.

Randel, W. J., Wu, F., Vömel, H., Nedoluha, G. E., and Forster, P.: Decreases in stratospheric water vapor since 2001: links to changes in the tropical tropopause and the Brewer-Dobson circulation, J. Geophys. Res., 111, D12312, doi:10.1029/2005JD006744, 2006.
Randel, W. J. and Park, M.: Deep convective influence on the Asian monsoon anticyclone and associated tracer variability observed with Atmospheric Infrared Sounder (AIRS), J. Geophys. Res., 111, D12314, doi:10.1029/2005JD006490, 2006.

Randel, W. J., Park, M., Wu, F., and Livesey, N.: A large annual cycle in ozone above the tropical tropopause linked to the BrewerDobson circulation, J. Atmos. Sci., 64 (12), 4479-4488, 2007.

Schiller, C., Krämer, M., Afchine, A., Spelten, N., and Sitnikov, N.: The ice water content of Arctic, mid latitude and tropical cirrus, J. Geophys. Res., 113, D24208, doi:10.1029/2008JD010342, 2008.

Sherwood, S. C. and Dessler, A. E.: On the control of stratospheric humidity, Geophys. Res. Lett., 27, 2513-2516, 2000.

Simmons, A. J., Untch, A., Jakob, C., Kallberg, P., and Unden, P.: Stratospheric water vapour and tropical tropopause temperatures in ECMWF analyes and multi-year simulations, Quart. J. Roy. Met. Soc., 125, 353-386, 1999.

Vaughan, G., Schiller, C., MacKenzie, A. R., Bower, K., Peter, T., Schlager, H., Harris, N. R. P., and May, P. T.: SCOUTO3 /ACTIVE: High-altitude aircraft measurements around deep tropical convection, B. Am. Meteorol. Soc., 89, 647-662, doi:10.1175/BAMS-89-5-647, 2008.

Vömel, H., Barnes, J. E., Forno, R. N., Fujiwara, M., Hasebe, F., Iwasaki, S., Kivi, R., Komala, N., Kyrö, E., Leblanc, T., Morel, B., Ogino, S.-Y., Read, W. G., Ryan, S. C., Saraspriya, S., Selkirk, H., Shiotani, M., Valverde Canossa, J., and Whiteman, D. N.: Validation of Aura Microwave Limb Sounder water vapor by balloonborne Cryogenic Frost point Hygrometer measurements, J. Geophys. Res., 112, D24S37, doi:10.1029/2007JD008698, 2007.

Zöger, M., Afchine, A., Eicke, N., Gerhards, M.-T., Klein, E., McKenna, D. S., Mörschel, U., Schmidt, U., Tan, V., Tuitjer, F., Woyke, T., and Schiller, C.: Fast in situ stratospheric hygrometers: A new family of balloonborne and airborne Lyman $\alpha$ photofragment fluorescence hygrometers, J. Geophys. Res., 104, 1807-1816, 1999. 